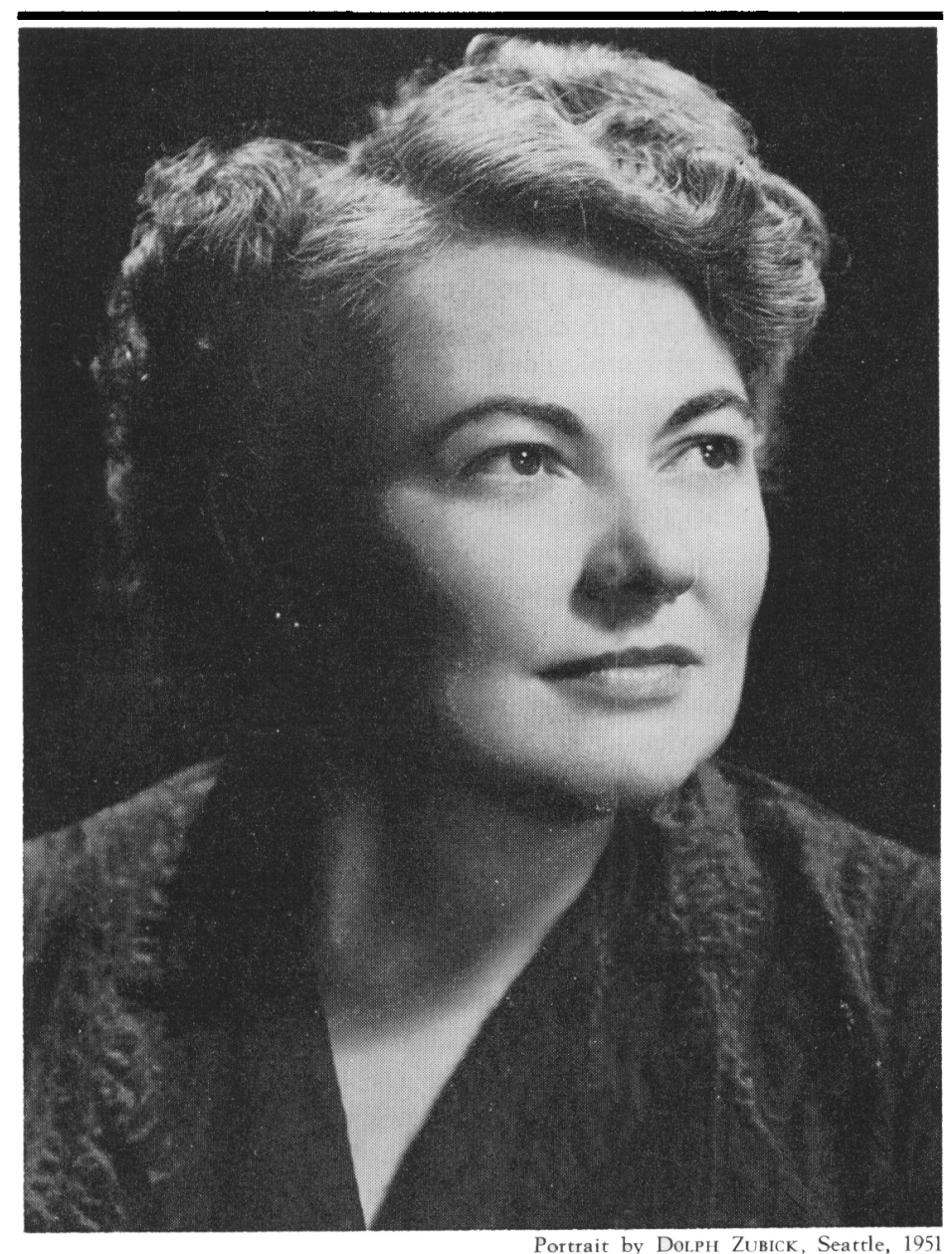

\title{
MARIAN WESLEY SMITH
}

\section{$1907-1961$}

Marian W. Smith (Mrs. H. F. Akehurst) was born in New York, May 10, 1907, and when she died in New York, May 2, 1961, after a gallant battle against a cruelly painful disease, we lost a colleague who embodied the finest traditions of American anthropology. Her own life was a record of struggle and achievement, and above all, of courage. Although crippled in one leg since the age of three, so that each step was made with great effort, she was not deterred from active ethnographic fieldwork in the Pacific Northwest (1935-36, 1938, 1945), and among the Sikhs of British Columbia and California (1943) and in the Punjab (1948-49). She did not hesitate to walk into the darkest city slums or to drive down the most remote reservation tracks. Characteristically, her interest in the Sikhs was aroused in 1941, when one appeared unexpectedly in her Columbia class on field methods in answer to a call for an informant.

In her triumph over a severe physical handicap and in the fortitude with which she bore her last fatal illness, the first symptoms of which had appeared in 1949, 
she reminds us of two earlier American anthropologists: Frank Hamilton Cushing (18571900) who drove his frail body to the limit of endurance, and W J McGee (1853-1912) who for 14 years recorded for medicine the progress of his own cancer. More than this, Marian Smith was Franz Boas' last student, and like him, conceived the study of man as one complete whole, to which each anthropological subdiscipline or specialized approach could make its best contribution only in conjunction with its fellows, viewed within the wide context of the whole world of man. Therefore, I shall not write particularly about her work in American archaeology, although it was a field in which she was interested and to which she made original contributions, but will try to exhibit what she stood for as a whole. This is because this totality is of significance to us all as anthropologists, and because archaeologists and culture historians seem to be particularly aware of its value.

Marian Smith did not carry prefabricated hypotheses into the field, although she had a keen sense of problem, but let understanding emerge from an "exhaustive collection of data ... systematically gathered [and] systematically ordered," to quote from her own description of Boas' "Natural History" approach (1959: 54). The warm personal qualities which endeared her to colleagues on both sides of the Atlantic and to informant-collaborators on the Northwest Coast and in India were coupled with a breadth of sympathy and intellectual insight that could sense the values in the most varied of anthropological points of view and materials.

She had the gift of stimulating others, and I am glad to acknowledge my own debt to her for encouraging me to formulate explicitly my ideas about the relationship between archaeological and ethnological materials. Many others must have had similar experiences, for she edited at least 16 volumes (for the Society for American Archaeology, American Ethnological Society, Columbia University Contributions to Anthropology, Wenner-Gren Foundation for Anthropological Research, Royal Anthropological Institute), ranging in subject matter from linguistics and archaeology, through the broad spectrum of ethnology, to culture and personality; she organized many programs and symposia (especially for Section $\mathrm{H}$ of the American
Association for the Advancement of Science, and for the Royal Anthropological Institute); she reviewed a wide range of anthropological publications, with full appreciation of their merits and charity for their deficiencies; and she also contributed many short notes, especially to the Journal of American Folklore and to Man, revealing the same ability to recognize anthropological significance in unlikely or varied materials. In her breadth of interests, in her devotion to the many organizations she served with distinction, and in the range of subjects she taught at different times, Marian Smith was an anthropologist of the Great Tradition.

Her own contributions of particular interest to readers of this journal are those dealing with the ethnology, archaeology, culture history, art, and personality of the Coast Salish and their neighbors. If her reconstructions of cultural development in this area were not always completely accepted, her ethnography of the Puyallup-Nisqually is one of the outstanding monographs on the North American Indian. She has also illumined the motives and patterns of Plains warfare, discussed the theory behind the Kon-Tiki expedition, and recounted the history of the American Ethnological Society. Most of her data on the Sikhs unfortunately remain unpublished.

Marian Smith received her B.A. in 1929, her M.A. (in Philosophy) in 1934, and her Ph.D. at Columbia in 1938. Her first job (1928-31) was with the Prognostic Testing Section of Western Electric. In 1937-41 she was an Assistant in Anthropology at Barnard College. From 1941 to 1951 she was an Instructor in Anthropology at the Columbia University Graduate School, but, because she was a woman, no advancement was offered to her, despite the fact that her sex was ignored when the exigencies of war made it necessary to entrust her with some undergraduate men's classes. But, of course, Marian Smith was not the first distinguished woman anthropologist at Columbia to suffer professional discrimination. Marian Smith also taught summer school at Barnard (1943), was Visiting Lecturer at Vassar (194446) and at New York University (1947), and taught at a summer session for the South Asia Regional Studies at the University of Pennsylvania (1950). The following year she was at the University of California, Berkeley, and at 
the University of Washington for the summer of 1951. In 1951-52, she was Associate Professor of Anthropology in the Foreign Service Institute in the Department of State.

In 1952 she married the English industrialist, H. Farrant Akehurst, of London, whom she had met in the Punjab. Although she often traveled with him abroad, and attended some anthropological meetings in this country, her professional life from now on obviously centered in London.

In leaving us, she left behind a distinguished record of service to American anthropology. She was, of course, Fellow of the American Anthropological Association, and member of the Society for American Archaeology. She had been council member (1945-47) and First VicePresident (1948-49) of the American Folklore Society. In 1945 she became Secretary of Section $\mathrm{H}$ of the American Association for the Advancement of Science, which she revitalized with well planned programs. In the American Ethnological Society she was successively Secretary-Treasurer (1940-42), Vice President (194344), President (1944-45), and Editor (194552). In the last position she was responsible for a distinguished series of publications, a number of which would never have appeared except for her recognition of their merits, her skillful guidance of young authors, and her devoted efforts in raising publication funds.

Perhaps, however, her career in England was more extraordinary and reflects more fully her unusual abilities. Elected Fellow of the Royal Anthropological Institute in 1952, that same year she began to teach part time at the London School of Economics, offering two courses: "Current Trends in American Anthropology," and "Psychology and Social Anthropology" (or as we would say, "Personality and Culture"). Raymond Firth (Man, Vol. 61, Art. 203, October 1961, p. 177) pays tribute to her contributions as a teacher, and also notes with what perceptive understanding she "maintained a balance between her American training and her British experience, blending her approach as a cultural anthropologist with the points of view developed in her association with social anthropologists in this country."

It was this very breadth of interest, legacy of her American background and training under Franz Boas, which, in 1956, brought the distinction of her unanimous nomination as Honorary
Secretary to the Royal Anthropological Institute. She thus became the only individual to have held high office in both the American Ethnological Society (founded 1842) and its younger sister, founded as the Ethnological Society of London in 1843. To quote from the obituary written by her predecessor in office, William Fagg, (Man, Vol. 61, Art. 204, p. 177): ". . . she had demonstrated [in her writings] that she was one of the very few anthropologists in the world who could see anthropology whole and grasp the philosophical problems which its study presents." And when he was searching for his successor, he saw in her "an ideal candidate" for a position which demanded some one who was "ready to foster impartially all the branches of anthropology and above all the holistic view of the sciences of man which preserves anthropology itself from disintegration" (p. 178). As he also wrote to the London Times (May 9, 1961): "Her charm, generosity and humanity quickly won her the admiration and affection of everyone in the institute or who had any dealings with it. Her great vitality, always coupled with a fine sense of humour, enabled her to carry on the honorary secretaryship for nearly four years almost as a full-time job. She handled the institute's business herself in all its aspects..." and we gather that under her secretaryship the financial affairs were set upon a firm foundation.

"Constantly, as she worked, she introduced practical innovations which are of permanent value, while at the same time preserving and strengthening traditional procedures which have stood the test of time. Special mention should be made of the highly successful series of symposia - on cross-disciplinary subjects such as race and race relations, tribal art and society, and the domestication of cattle which she organized and which are now an important part of the institute's activity. But her reforming and conciliating influence pervaded all its work, and the transformation which she effected in it, without ever doing violence to its well established objects, will profoundly affect its future and that of British anthropology itself."

Could a more moving tribute be paid to Marian Smith, or to those values of anthropology which we cherish?

Frederica de Laguna 
Selected Publications in American

\section{ArchaEology and ETHNOLOGY}

1938

The War Complex of the Plains Indians. Proceedings of the American Philosophical Society, Vol. 78, Pt. 3, pp. 425-64. Philadelphia.

1940

The Puyallup-Nisqually. Columbia University Contributions to Anthropology, Vol. 32. New York.

The Puyallup of Washington. In "Acculturation in Seven American Indian Tribes," edited by Ralph Linton, pp. 3-36. Appleton-Century, New York.

\section{1}

A Note on Extinct Fauna and Man. American Antiquity, Vol. 7 , No. 1, p. 69 . Menasha.

The Coast Salish of Puget Sound, American Anthropologist, Vol. 43, No. 2, pp. 197-211. Menasha.

\section{3}

Columbia Valley Art Style. American Anthropologist, Vol. 45, No. 1, pp. 158-60. Menasha.

\section{6}

Petroglyph Complexes in the History of the ColumbiaFraser Region. Southwestern Journal of Anthropology, Vol. 2, No. 3, pp. 306-22. Albuquerque.

\section{7}

House Types of the Middle Fraser River. American Antiquity, Vol. 12, No. 4, pp. 255-67. Menasha.

\section{9}

Indians of the Urban Northwest (EDrTOR). Columbia University Contributions to Anthropology, Vol. 36. New York. Salish Coiled Baskets (with Dorothy LEADBEATER). Columbia University Contributions to Anthropology, Vol. 36, pp. 111-32. New York.

\section{0}

Archaeology of the Columbia-Fraser Region. Memoirs of the Society for American Archaeology, No. 6. Menasha.

The Nootsack, the Chilliwack and the Middle Fraser. Pacific Northwest Quarterly, Vol. 41, No. 4, pp. 33041. Seattle.

\section{1}

American Indian Warfare. Transactions of the New York Academy of Sciences, Vol. 13, No. 8, pp. 34865. New York.

1952

Culture Area and Culture Depth: with Data from the Northwest Coast. In "Indian Tribes of Aboriginal America," Proceedings of the 29th International Congress of Americanists [New York, 1950], Vol. 3, edited by Sol Tax, pp. 80-96. University of Chicago Press, Chicago.

Different Cultural Concepts of Past, Present, and Future, A Study of Ego Extension. Psychiatty, Vol. 15, Pt. 4, pp. 395-400. Washington. [Includes Coast Salish data.]

Basketry Design and the Columbia Valley Art Style (with Harold J. Gowers). Southwestern Journal of Anthropology, Vol. 8, No. 3, pp. 336-41. Albuquerque.

The Theory Behind the Kon-Tiki Expedition (a review of Thor Heyerdahl, "American Indians in the Pacific," 1952). Geographical Journal, Vol. 19, Pt. 4, pp. 471-6. London.

Asia and North America: Transpacific Contacts (FDITOR). Memoirs of the Society for American Archaeology, No. 9. Salt Lake City.

\section{4}

Attributes and the Discovery of Projectile Point Types: With Data from the Columbia-Fraser Region. American Antiquity, Vol. 20, No. 1, pp. 15-26. Salt Lake City.

Shamanism in the Shaker Religion of Northwest America. Man, Vol. 54, Article 181, pp. 119-22. London.

\section{5}

Continuity in Culture Contact: Examples from Southern British Columbia. Man, Vol. 55, Article 115, pp. 100-5. London.

$$
1956
$$

The Cultural Development of the Northwest Coast. Southwestern Journal of Anthropology, Vol. 12, No. 3, pp. 272-94. Albuquerque.

\section{9}

Boas' "Natural History" Approach to Field Method. In "The Anthropology of Franz Boas: Essays on the Centennial of his Birth," edited by Walter Goldschmidt, pp. 46-60. Memoirs of the American Anthropological Association, No. 89. Menasha. 